\title{
ノニオンーアニオン混合活性剤による塩化ビニリデン・塩化 ビニルラテックスの生成条件におよぼす電解質の影響†
}

(昭和 40 年 2 月 10 日受理)

$$
\text { 公 井宗 一* }
$$

䉓解質存在下に括けるノニオンーアニオン混合活性剤による壏化ビニリデン・監化ビニルラテックスの生成条件の検討 を行なった。エチレンオキシド付加モル数の種々異なるノニルフェノール付加物と, 2 種のタイブのアニオン活性剤を種 々の割合に混合して用いて乳化重合を行なった結果, 重合中に生成する凝固物の量は, 電解質が存在しない場合には, 混 合組成のほぼ中間に执いて極大を示すが，電解質が存在する場合には，アニオン活性剤の混合率の增加とともに，急激に 減少すること, 怙よび重合初速度は混合組成に応じてそれぞれの初速度のほほ中間の值を示すが, ラテックス粒子は混合 率の增加とともに急速に小さくなることを見出した。さらに, 電解質の添加量が適当であるときには, それぞれ単独でよ

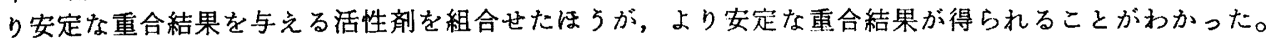

\section{1 粕言}

従米ノニオン活性剂単独では円滑な重合を行なうことが困難と されていた眯水性モノマーも, 活性剂扣よび重合条件の適当な選 択によって，円滑に重合を行ない得ることが示されたが1)，活性 剤据よび重合条件の選択は，アニオン活性剤による場合に比較し て，著しくはん雑である。そこで，優れた化学的安定性や顔料と の混和性が要求される場合には, 安定な重合結果を与えるノニオ ン活性剂がすでに明らかになっている場合は別として，新たに活 性剂を選択する必要のあるときには，むしろノニオンーアニオン 混合活性剤によって目的の性質を与えるように努力するほうが容 易であろ5。

従来, ノニオンーアニオン混合活性剂による疎水性モノマーの 乳化重合の研究は多数行なわれているが2 4), 混合活性阂の選択 を系統的に行なった例は少なく，代表的な例としては HLB の明 らかなアニオン活性剤を用いて，HLB 系の適用によって，HLB と重合安定性およびラテックスの諸性質との関係について研究し たGreth ら゙)の報告があげられる程度である。しかし，アニオン 活性剤は一般に HLB の不明なものが多いので, 多くの場合に は，HLB 系の適用は困難である。そこで単独での重合結果の明 らかな 3 種のエチレンオキシド付加モル数 $(n)$ の異なるポリオ キシェチレンノニルフェニルェーテル (PNE) と, 2 種のタイプ の全く異なるアニオン活性剤, ドデシルベンゼンスルホン酸ナト リウム (DBS) 扣よび $n=20$ のポリオキシェチレンノニルフェ ニル硫酸ナトリウム(PNS) を組合せて, 塩化ビニリデン (VD)

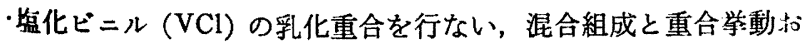
よび得られるラテックスの性質との関係について検討を加えて， 混合活性剤の系統的な選択方法について知見を得ようとした。ま

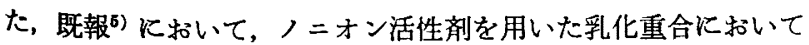

†本報を「合成樹脂ラテックスの製造と応用に関する研究 (第 3 報)」とする.

* Soichi MUROI 旭化成工業（株）商品開発研究所: 東京都 板橋区中台 3 丁目.

1) 室井, 工化 68,1779 (1965).

2) H. Naidus, Ind. Eng. Chem. 45, 712 (1953).

3) A. F. Helin, et al., Ind. Eng. Chem. 45, 1330 (1953).

4) G. G. Greth, J. E. Wilson, J. Appl. Polymer Sci. 5 , 136 (1961).

5) 室卡，工化 68, 1773 (1965).
は, 電解質の添加は重合安定性にアニオン活性剂の場合 ${ }^{6)}$ とっ たく逆の影響を拈よぼすことが眀らかにされているので，泚合活i 性片系の場合には，電解質の重合安定性に拉よぼす影響について 北常な興味がもたれる。そこで, 乳化重合は規定の濃度のリン酸 ニナトリウム (DHP) の存在下に执いて行なってみた。

\section{2 実 験 方 法}

\section{$2 \cdot 1$ 実験材料}

DBS 拈よび PNS は市販品を減圧乾燥後メタノールより 2 區

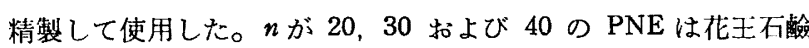
（株）の後好意により，特別に調製して頂いた試料を减圧乾燥し て用いた。

モノマー，過硫酸アンモニウムおよび DHP は既報占に用いた とまったく同じものを使用した。

\section{$2 \cdot 2$ 乳化重合}

本実験に持ける乳化重合には，すべて表 1 の配合を用いた。重 合は既報5)に述べた方法とま ったく同様にして, $50^{\circ} \mathrm{C}$ に おいて，振りまぜ速度 54.5 回 $/ \mathrm{min}$ 振りまぜ距離 $125 \mathrm{~mm}$ で, 水平方向に振りまぜるこ とによって行なった。 表 1 重合配合

\begin{tabular}{|c|c|}
\hline 配 合物 & 重典部 (g) \\
\hline VD & 20.00 \\
\hline $\mathrm{vCl}$ & 20.00 \\
\hline 界面活性凨 & 1.60 \\
\hline 過硫酸アンモニウム & 0.08 \\
\hline DHP & $x$ \\
\hline 脱イオン水 & $38.32-x$ \\
\hline
\end{tabular}

\section{$2 \cdot 3$ ラテックスの性買の測定方法}

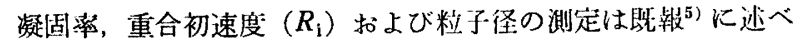
たのとまったく同じ方法で行なった。

\section{3 実 験 結 果}

\section{$3 \cdot 1$ 重合安定性}

合成樹脂ラテックスを製造する場台に, 最も重要なのは重台の 安定性であり, 重合速度または重合時間は, よほど著るしい相違 がなければ，あまり大きな問題とはならない。重合安定性の目安 となるのは，重合過程に拈いて生成する凝固物の量であるが，界 面活性剤が目的とするモノマーの乳化重合に完全に不適でなく, 比較的少ない凝固物の生成量で, 重合を行ならことが可能であれ ば,一定の重合条件下に扣いて，生成する凝活物の量は，能報1 に亦したごとくかなりよい再晛性を示す。

6) L. H. Howland, et al., Ind. Eng. Chem. 44, 762(1952). 
DHP の量を無添加, 0.5 および $1.0 \%$ と変え， $n=20,30$ 打 よび 40 のPNE と DBS, および $n=30$ の PNE とPNS の組 合せで, 混合比率を変えて, PNE-DBS 系については 40 時間,

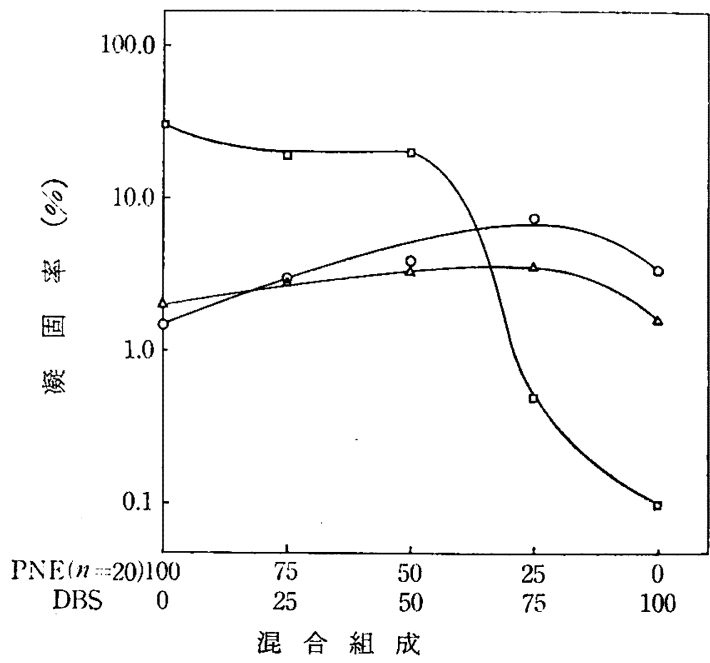

困 $1 \operatorname{PNE}(n=20)-\mathrm{DBS}$ 系の凝固率

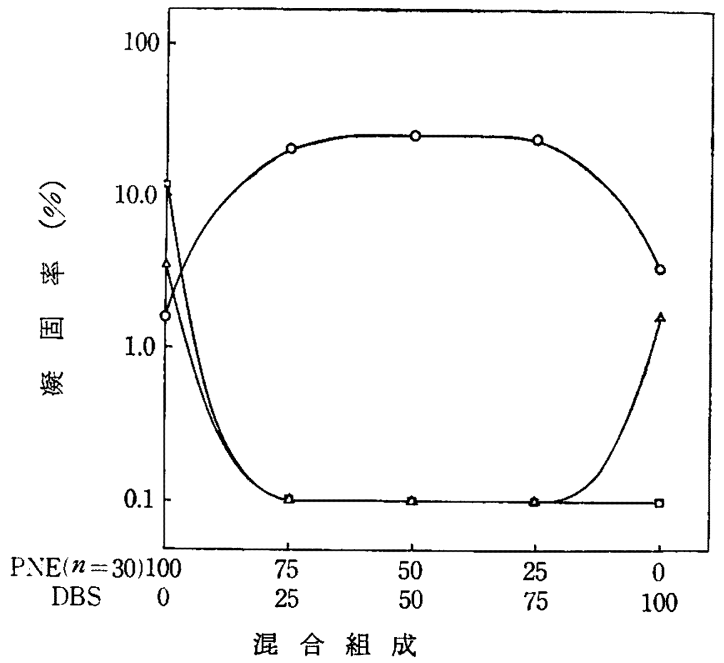

図 $2 \operatorname{PNE}(n=30)-\mathrm{DBS}$ 系の凝固率

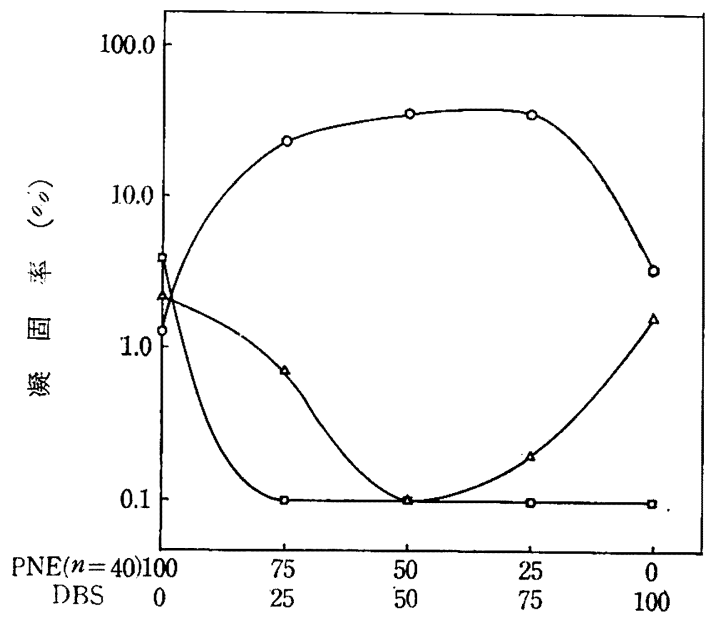

混合組成

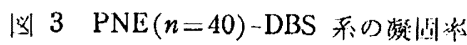

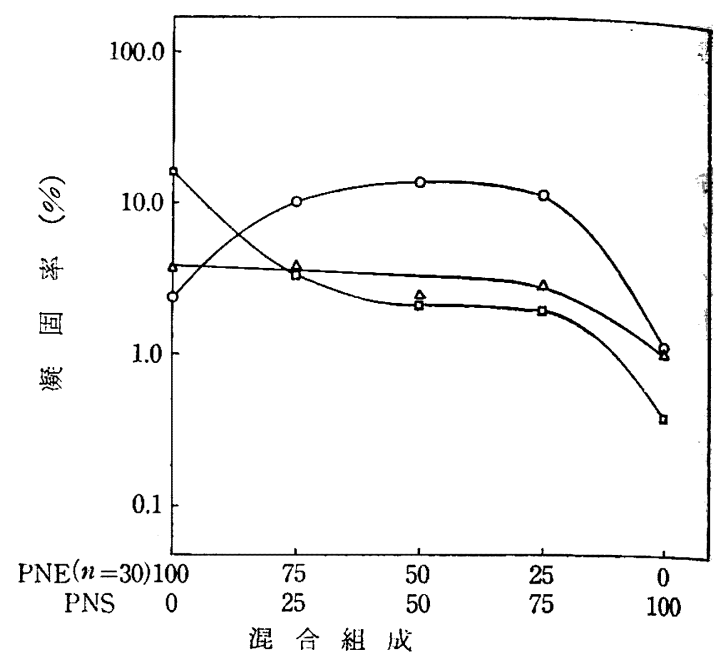

図 $4 \operatorname{PNE}(n=30)$-PNS 系の凝固染

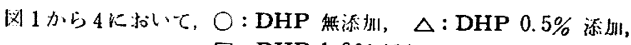
口: DHP $1.0 \%$ 添加

PNE-PNS 系については 50 時間重合したときの凝固率を, 重合 安定性の目安として因 1 から 4 亿示す。な打 DHP の添加量は水 相中の濃度で示した。

本実験に使用した 2 種のアニオン活性剂のうち, DBS は従来 $\mathrm{VD} \cdot \mathrm{VCl}$ を乳化重合するのに最も適した活性剤のひとつにあげ られているが，PNS についてはあまり明らかではない。DBS で 乳化重合を行なった場合には, 凝固染は DHP 添加量の增加とと もに急激に低下するが，PNS の場合には，DHP 添加の影響をあ まり大きく受けない。従って DHP 添加量の少ないところでは, DBS と PNS の重合安定性には，あまり朴逢はみられないが， DHP の添加量が多くなると DBS のほうがはるかに安定な重合 結果を与える。

ノニオン活性剂については, 本赛験の結果のみでは, 表 2 に示 すごとく重合率が低いために，nの相違による重合安定性の差異 がはっきりしないが，既報ら)の結果によれば，ほぼ 100\%の重合 率に拈いては, DHP 0.5\% 添加で, $n=30$ 执よび 40 の PNE の凝固率は $5 \%$ 以下であるのに対して， $n=20$ の PNE の凝固 率は 40\% 以上にも達する。これらのノニオン活性剂を用いて乳 化重合を行なった場合の DHP 添加の効果は, 図 1 から4 に見ら れるごとく，アニオン活性剤の場合とまったく逆であり，凝固率 は DHP 添加量の增加とともに著るしく增加する。

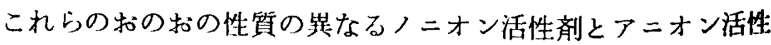
剂とを組合せて乳化重合に用いると，得られる重合結果もまたそ

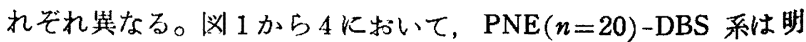
らかに不適であり、テニオン活性剈の混合比率がかなり高くなっ ても満足すべき重合結果が得られないのに対し，他の混合系に拈 いて，DHP の添加量が適当で岁れば，十分に満足すべき重合安 定性が得られる。この後者の 3 種の混合系に扣いて共通な点は, DHP 無添加のときに，混合率の中間に扣いて凝固率に極大がみ られることである。PNE-DBS 系に扎いては，DHPを0.5\%添 加したときには，逆に混合率の中閂に凝固率の極小が見られる が、これはあまり大きなるのではない。

DHP 泒加唶が $1.0 \%$ の点に抽いて, DBS と PNS を比較す

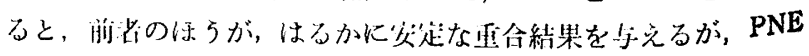


と組合せた場合にもこの傾向は見ら れ, PNE-DBS の系においては, 75 : 25 ですでに安定な重合結果が得られ るにもかかわらず, PNE-PNS の系に おいては, アニオン活性剂混合の重合 安定性に対する寄与は著るしく低く, 同じ混合率に批いては，前者に比較し

\begin{tabular}{|c|c|c|c|c|c|c|c|c|c|c|c|c|}
\hline \multirow[b]{2}{*}{$\frac{\text { d: 合率 }}{\text { オニ }}$} & \multicolumn{3}{|c|}{$\operatorname{PNE}(n=20)-\mathrm{DBS}$} & \multicolumn{3}{|c|}{$\operatorname{PNE}(n=30)-\mathrm{DBS}$} & \multicolumn{3}{|c|}{$\operatorname{PNE}(n=40)-\mathrm{DBS}$} & \multicolumn{3}{|c|}{$\operatorname{PNE}(n=30)$-PNS } \\
\hline & 鿏添加 & $\begin{array}{l}0.5 \\
0.5 \\
(\%)\end{array}$ & $\begin{array}{l}11 \\
1.0 \\
(\%)\end{array}$ & 篗添榇 & $\begin{array}{l}0.5 \\
\%\end{array}$ & $\begin{array}{l}1 " 0 \\
1 \%) \\
(\%)\end{array}$ & DHP & $\begin{array}{l}0.5 \\
(\%)\end{array}$ & $\begin{array}{l}1.0 \\
(\%) \\
(\%)\end{array}$ & $\underset{\text { 無添牒 }}{\text { DP }}$ & $\begin{array}{l}0.5 \\
(\%)\end{array}$ & $\begin{array}{l}1.0 \\
(\%)\end{array}$ \\
\hline $100: 0$ & 28.2 & 32.5 & 31.4 & 64.2 & 83.4 & 56.2 & 67.4 & 80.7 & 74.8 & 76.6 & 92.2 & 84.9 \\
\hline $75: 25$ & 83.9 & 43.6 & 29.8 & 94.3 & 96.1 & 91.5 & 88.6 & 88.1 & 94.8 & 96.5 & 97.6 & 96.5 \\
\hline $50: 50$ & 91.0 & 96.8 & 24.9 & 96.3 & 96.0 & $95 . \mathrm{C}$ & 100.0 & 97.1 & 96.3 & 94.6 & 97.8 & 96.6 \\
\hline $25: 75$ & 96.3 & 99.3 & 97.3 & 96.8 & 96.8 & 96.3 & 99.8 & 97.3 & 98.0 & 91.7 & 98.8 & 97.0 \\
\hline $0: 100$ & 98.3 & 98.3 & 99.3 & 98.8 & 98.3 & 99.3 & 98.8 & 98.3 & 99.3 & 99.8 & 99.0 & 97.2 \\
\hline
\end{tabular}

て凝固率ははるかに高い。

各活性剤を単独に使用した場合には，上述したごとく，ノニオ ン活性剤に怙いては， $n=30$ および $n=40$ の活性剤では重合安 定性はほぼ同様であるが， $n=20$ の活性剤のそれは著るしく劣 る。またアニオン活性剤においては，DBS のほ5が優れた重合 安定性を示す。これらの活性剤の特徵は混合してもあらわれ， $n$ $=30$ および, 40 の PNE-DBS 系においては, DHP 添加量が適 当であれば，ノニオン活性剤の高い混合比率のところでも安定に 重合を行ない得るのに対して，PNE-PNS 系ではアニオン活性剤 の高い混合比率のところで，乙かもかなり高い凝固率でしか重合 を行ない得ない。 $n=20$ の PNE にいたっては DBS と組合せて も安定な重合絬果を得ることは不可能である。

DHP の重合安定性に扣よぼす効果は，ノニオン活性剂：アニ オン活性剂=75:25 の混合比率ですでに反転しているが，この 反転がどの程度の混合率で起きたかは，本头験の結果からは知る ことはできない。

\section{$3 \cdot 2$ 重合初速度}

ノニオン活性剤を単独に用いて乳化重合を行なら場合に問題と なるのは，重合安定性以外にはその重合速度の括そさである。そ こで各混合活性剤について $R_{\mathrm{i}}$ ，および PNE-DBS 系については 40 時間， PNE-PNS 系については 50 時間重合して重合率を測 定してみた。結果を図 5 扰よび 6 ，拉よび表 2 に示す。な拈 $R_{\mathrm{i}}$ の測定は PNE-DBS 系の全部について行なったが，同じような 傾向が得られたので, 図 5 には $\operatorname{PNE}(n=30)-\mathrm{DBS}$ 系についての み示した。

PNE-DBS 系においては， $R_{\mathbf{1}}$ はアニオン活性剤の混合率の增 加とともに增加するが，活性剤の混合摔- $R_{\mathrm{i}}$ 曲線は DHP の添加 量によって買なり，DHP を添加した垐合には，それぞれ単独で の $R_{\mathrm{i}}$ を結ぶ值線を上回るのに対して，無添加の場合には下回る。 DHP 㮇添加の場合のこの傾向は，混合率の中間に括ける凝固率

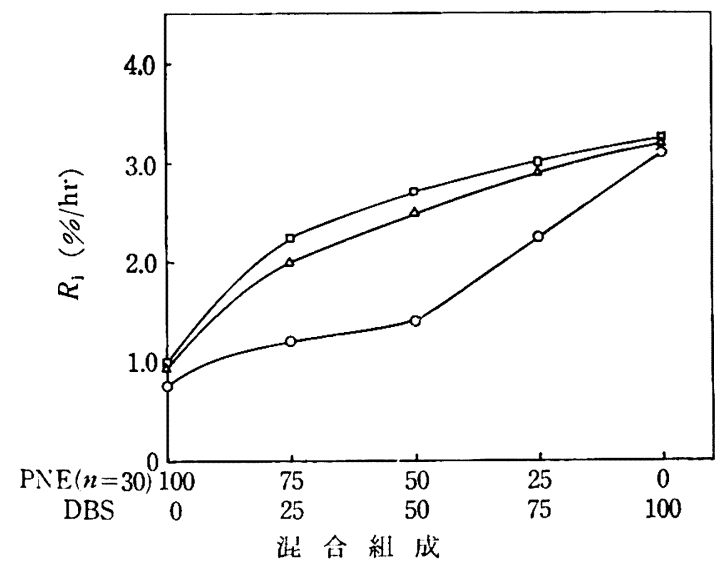

困 $5 \operatorname{PNE}(n=30)-\mathrm{DBS}$ 系での混合組成と $R_{1}$ の関倸

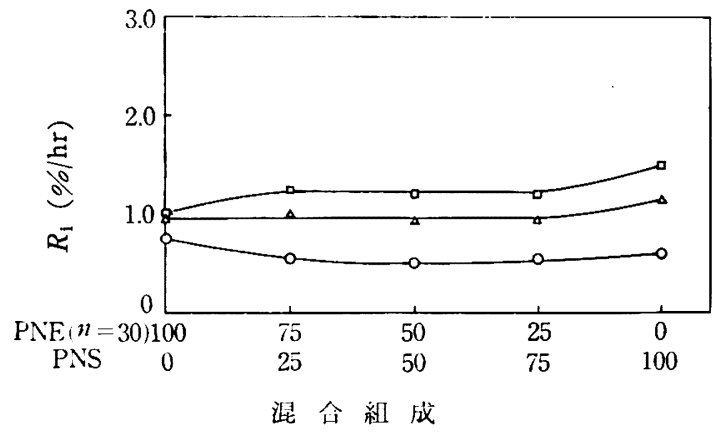

困 $6 \mathrm{PNE}(n=30)$-PNS 系での混合組成と $R_{\mathrm{i}}$ の関倸

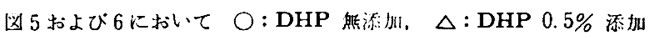
口: DHP $1.0 \%$ 添加

の著しい增加によるのと考えられる。この場合にもアニオン活 性剂 $\left.{ }^{7}, 8\right)$ 扣よびノニオン活性剂(5) の場合と闹様に電解質の添加に よる $R_{\mathrm{1}}$ の增加が恋められる。PNE-PNS 系に执いては，それぞ れの $R_{1}$ が近似しているために, PNE-DBS 系に比較して变化の 度合は少ないが，同じ様な傾向が観察される。

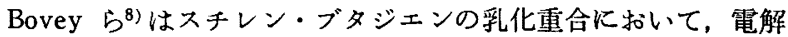
質を添加すると $R_{1}$ は增加するが，高重合率に招いては電解質を 添加したほうの重合率は，無添加のそれに比較して，かなり低く なることを見出している。 $\mathrm{VD} ・ \mathrm{VCl}$ の乳化重合においても，上 述のごとく, 䉓解質の添加による明らかな $R_{1}$ の增加が観察され るが，高重合率に括いては，表 2 に示したように䉓解質の添加の 影賠は見られない。このことは逆に $R_{\mathrm{i}}$ と重合を完了させるのに 必要な時間との間には，明らかな相闺阅係がないことを示してい る。

\section{$3 \cdot 3$ 粒子径}

料子径は，即報と同様に， $0.5 \mathrm{~g} / l$ にうすめた試料ラテックス の吸光度であらわした。 $\operatorname{PNE}(n=30)-\mathrm{DBS}$ 系および $\operatorname{PNE}(n=$ 30)-PNS 系について得られた测定結果を図 7 および 8 に示す。 他の混合活性剤系についてもまったく同じ傾向の曲緗が得られた が省略した。なお吸光度と粒了径との间には正の相関関係のある ことが恋められているので〜11), 吸光度によって, 相対的に粒子 径を論議することに問題はないものと考えられる。

ノニオン活性剤: アニオン活性剤 $75: 25$ までは, アニオン活 性剂の混合率の增加とともに粒子径は急激に小さくなるが，それ 以上に括いては，粒子径の変化は次第に少なくなる。この傾向は

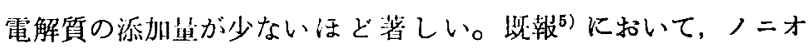

7) J. W. L. Fordham, H. L. William, Ind. Eng. Chem. 47, 1714 (1955).

8) F. A. Bovey, et al., “Emulsion polymerization", Interscience Pub. Inc., New York (1955), p. 346.

9) 本山, 润村, 工化 58, 113 (1955).

10) 三浦, 工化 64, 405 (1961).

11) 加来, 樹脂加工 12, 210 (1963). 


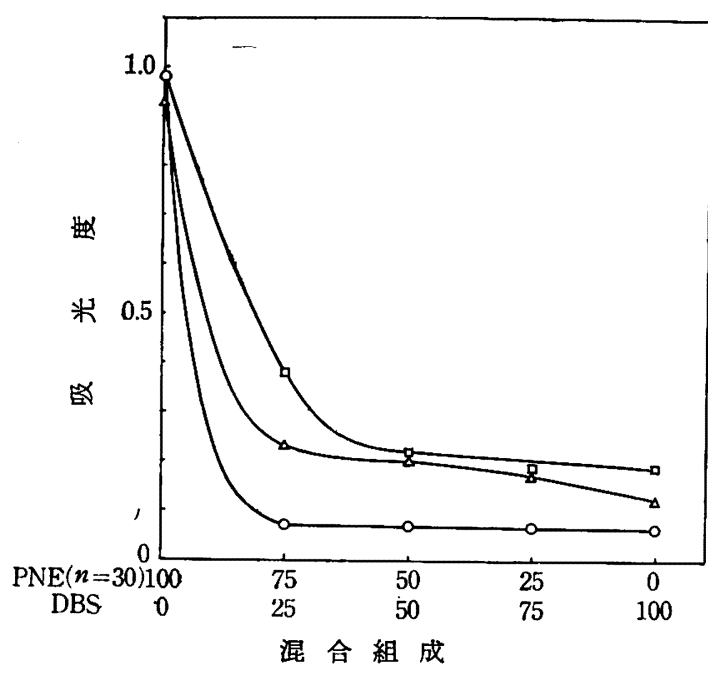

図 7 PNE $(n=30)-D B S$ 系での混合組成と吸光度の関係

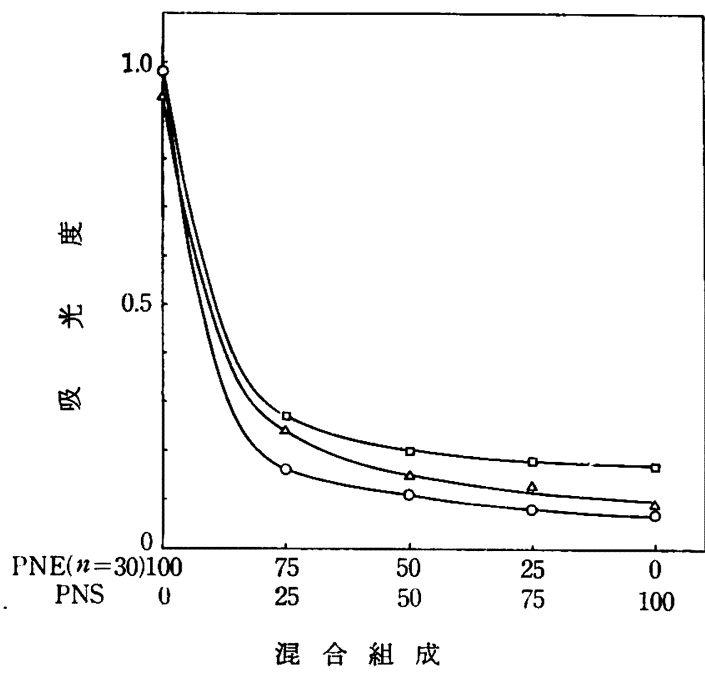

戍 $8 \operatorname{PNE}(n=30)-\mathrm{PNS}$ 系での混台組成と吸光度の関係 内 7 およびに 8 おいて O: DHP 無源加， $\triangle$ : DHP 0.5\% 添加 $\square:$ DHP $1.0 \%$ 添扣

ン活性剤监独で重合を行なった場合に，粒子径は， $n=40$ まで は，nの增加とともに小さくなることを示したが，75:25 の混 合率に拈いては，まだこの影響が僅かにみられる。しかし，50： 50 以上では，ノニオン活性剂の $n$ による相違はまったくみられ なくなる。

粒子径におよぼす DHP 添加の効果は，混合活性阂において も，アニオン活性剤と同様に観察される ${ }^{7,12)}$ 。加来 ${ }^{12)}$ はこの効果 は DHP 添加による $\mathrm{pH}$ の変化には無関係であり, $\mathrm{Na}^{+}$濃度の ミセル構造におよぼす影響によることを見出している。また，三 浦 $^{13)}$ はノニオン活性斉の混合率が增加するとともに，ラテックス の凝析価が著しく增大することを示しているが，本実験の結果で は, 電解質添加の粒子径におよぼす効果はノニオン活性剤の混合 摔にはほとんど無関係である。これらの結果からみて，混合活性 淿に扣ける電解質の源加による粒子径の增大は, アニオン活性剂 の場合と同様に，ミセル棈造の变化によるものと考えるのが妥当 なようである。

12) 加来, 樹脂加工 12, 289 (1963).

13) 三浦, 工化 64, 412 (1961).
PNE-PNS 系の混合率-吸光度曲線は PNE-DBS 系のそれとは とんど同じである。PNS は $n=20$ のポリオキシェチレン鎖を含 むにもかかわらず, DBS と同じように，DHP 添加による影響を 受ける。PNS で得られるラテックスの粒子径は，DBS で得られ るそれとほとんど同じであるが，PNS の分于量は DBS のそれ に比べて著しく高いことから，PNS の形成するミセルは非常に 小さいと考えられる。他方，同じ大きさのラテックス粒子を生成 するにもかかわらず， PNS の $R_{\mathrm{i}}$ が DBS のそれに比較してか なり小さいことから，この小さなミセルの可溶化力もまた小さい ことがわかる。

\section{4 放置安定性}

DHP 添加の放㨁安定性におよぼす影響をしらべるために，凝 固率を湘定したときに得られたラテックスを，室温に㨟いて，約 3 カ月間放置してみたが，ノニオン活性剤を単独に使用して得ら れたラテックスに沈降が生じた以外は, 変化の生じたラテックス はなかった。この結果から，本実験に用いた程度の少量の電解質 は，放誢安定性にまったく影響をおよばさないとみなしてもよい と考えられる。

\section{4 考察}

本实験においては，ノニオンーアニオン混合活性荗を用いて， 電解質無添加で乳化重合を行なった場合に, 混合組成の中間にお いて，凝固率の極大が生ずるとい5現象が観察された。この現象 は従来報告されて招らず，かつノニオン活性剤とアニオン活性剂 の重合安定化機構の相違, およびラテックス粒子界面に打ける活 性剂の吸着状態と重合安定珄との関係について，知見を得るため の格好の現象と考えられるので，以下にこの現象を中心として重 合安定性の問題について論議してみた。

本実験に用いた混合活性剂系については， $\operatorname{PNE}(n=20)-\mathrm{DBS}$ 系を除いては，すべて同じような混合組成一凝固率曲線扣よび混 合組成一吸光度曲線が得られたので， PNE $(n=30)-\mathrm{DBS}$ 系を代表 例に選んだ。まずこの 2 種の活性剂の分子量执よびボリスチレン 粒子に対する吸着断面積を衣 3 に示す。な扎比較のために PNS の分子量も示した。Orr ${ }^{14)}$ によれば，活性剂の吸着断面積は，ポ リマー組成の影響を受けないことが諗められているので，この測 定値を $\mathrm{VD} \cdot \mathrm{VCl}$ に適用しても問題はないと考えられる。

表 3 活性珮の分子量および吸着断面槕

\begin{tabular}{|c|c|c|}
\hline 话 姓 剂 & 分子真 & 吸部断面错 \\
\hline DBS & 348 & $49 \AA^{2}$ \\
\hline PNE & 1540 & $101 \AA^{2}{ }^{15)}$ \\
\hline PNS & 1202 & - \\
\hline
\end{tabular}

汹 7 扰よび 8 に示したよ5に, ラテックスの粒子径はアニオン 活性放の混合率の增加とともに小さくなるが, 粒子の全界面面積

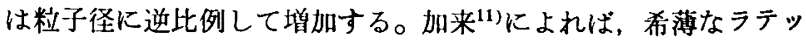
クスの透過率 $T$ と粒子径 $d$ との間には矢験的に $\log d=-k \log T$ の関係が成立することが見出されているので，吸光度のデータか ら粒子径を求め, $1 \mathrm{~m} l$ のラテックス中の粒子の界面面積 $S_{\mathrm{p}}$ を, PNE を単独に使用して得られたラテックスの $S_{\mathrm{p}}$ を1として相 刘的にあらわせば，アニオン活性剤の混合率の增加に伴な5 $S_{\mathrm{p}}$ の増加は図 9 に示した尖線のようになる。な扰透過率から粒子径

14) R. J. Orr, L. Breitman, Can. J. Chem. 38, 668(1960).

15) L. Hsiao, et al., J. Phys. Chem. 60, 657 (1956). 
を求めるさいに，头測値は $0.4 \mu$ までしか得られていなかったの でそれれ上の粒子柊は外插倠としてしか得られなかった。この ために大きな粒子径については信頼度が低いが，この場合は，そ れほど問題にはならないものと考えられる。また PNE で得られ たラテックスの粒子径には, 電解質無添加のときの值を使用し,

\section{電解質の影響は無視した。}

他方，本実験においては，一定重量の活性剂を使用しているの で, 活性阂の吸着被覆し得る面積は,アニオン活性剤の混合率の 增加とともに增加する。いま $1 \mathrm{ml}$ のラテックス中に含まれる活 性阂の吸着被覆し得る面積を， $S_{\mathrm{a}}$ であらわし，PNEの $S_{\mathrm{a}}$ を 1 とすれば,アニオン活性剤の混合率の增加に伴なら $S_{\mathrm{a}}$ の増加は, 図9中に示した破線のようになる。

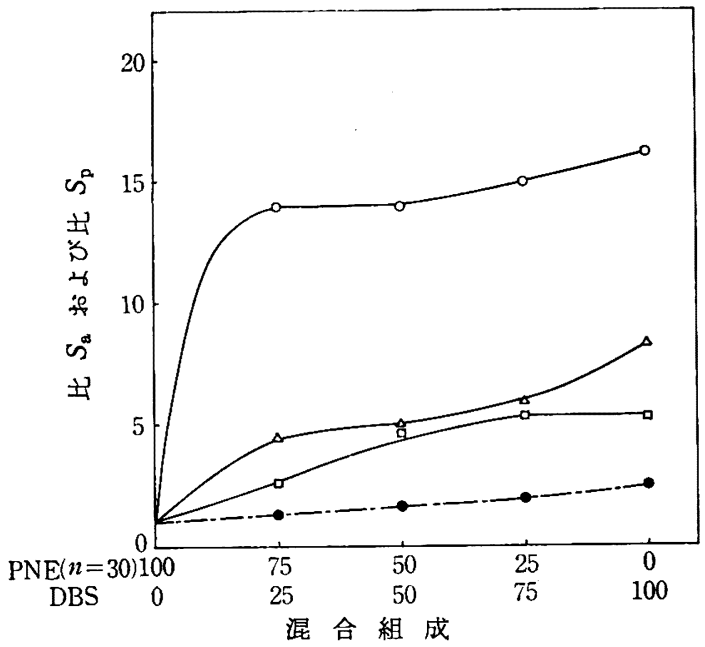

図 $9 \mathrm{PNE}(n=30)-\mathrm{DBS}$ 系での混合組成 と $S_{\mathrm{a}}$ 扰よび $S_{\mathrm{p}}$ との関係

- : $S_{\mathrm{a}}, \quad \mathrm{O}: \mathrm{DHP}$ 無添㧈のときの $S_{\mathrm{p},} \quad \triangle: \mathrm{DHP}$ を $0.5 \%$ 添加 したときの $S_{\mathrm{p}}, \square: D H P を 1.0 \%$ 添加したときの $S_{\mathrm{p}}$

同図より， $S_{\mathrm{a}}$ の增加に比べて， $S_{\mathrm{p}}$ の增加は著しく大きく，ま た $S_{\mathrm{a}}$ と $S_{\mathrm{p}}$ との差迋は電解質の添加量が少ないほど大きいこと がわかる。

次に $S_{\mathrm{a}} / S_{\mathrm{p}}$ を求めて圀 10 に示した。 $S_{\mathrm{a}} / S_{\mathrm{p}}$ はラテックス粒子

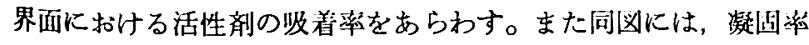
がほほPNE 単独で重合したときの凝固梁, 約 3\%となるよう な仮想線を点線で示した。

同図より電解質無添加の場合に混合組成の中間において，凝固 率の極大が生ずるのは，低い $S_{\mathrm{a}} / S_{\mathrm{p}}$ に起因することは明らかであ る。他の原因としては，乳化重合を安定に行ない得る活性剂の限 界吸着率，すなわた点線で示した曲線がアニオン活性剤の混合率 の增加とともに低くなることがあげられる。

このアニオン活珄剂の混合率の增加に伴な5限界吸着率の低下

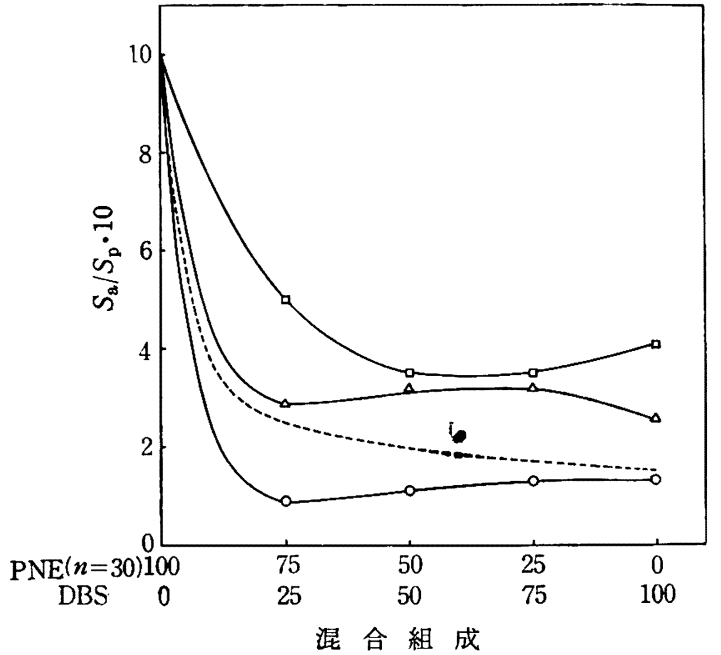

因 $10 \operatorname{PNE}(n=30)-\mathrm{DBS}$ 系での混合組成と $S_{\mathrm{a}} / S_{\mathrm{p}}$ の関倸

O:DHP 無添加, $\triangle$ : DHP 0.5\% 添加， $\square:$ DHP $1.0 \%$ 添加 -.-. : 凝固率力約 $3 \%$ となる $S_{\mathrm{a}} / S_{\mathrm{p}}$ の仮热線

は, 明らかにアニオン活性剤の吸着によって形成される電気 2 重

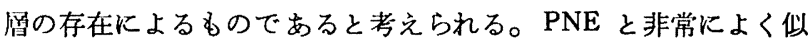
た構造の PNS は, 分子量の大きさが PNE とほぼ同程度である にもかかわらず，DBS で得られる粒子径とほとんど同程度の粒 子径のラテックスを比較的安定に生成し得ることからも, 電気 2 重層の存在は重合安定性に非常に大きく寄与することがわかる。

これらの結果から，ノニオンーアニオン混合活性剤を用いて, ノニオン活性剤の混合率の高いところで乳化重合を行なう場合に は，ノニオン活性阂の保護効果が，アニオン活性剤のそれよりも 劣り, かつアニオン活性剤の混合によって, 生成するラテックス の粒子径が小さくなることに起因する凝固物の生成量の增加を避 けるために，電解質の添加が必須の条件となることがわかる。他 方, 電解質の泒加量をできるだけ減らすためには，おの打の単独 に用たときに得られるラテックスの粒子径があまり著しく買なら ない活性剤同志および保護効果の高い活性剤を組合せることが必 要である。

本然験に扣いては，一定重量の活性剂しか使用しなかったが， Smith-Ewart ${ }^{16)}$ の式に従えば，粒子数は活性放濃度の $3 / 5$ 乘に

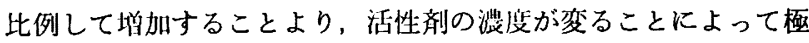
大の高さは変ったとしても，相対的な傾向は変らないものと考兄 られる。

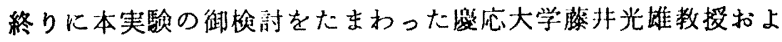
び界面活性剂を合成して顶いた花王石臉（株）に感謝します。

16) W. V. Smith, R. H. Ewart, J. Chem. Phys. 16, 592 (1948). 